\title{
Distribution, biomass and community structure of megabenthos of the Gulf of Carpentaria, Australia
}

\author{
Brian G. Long*, Ian R. Poiner, Ted J. Wassenberg \\ CSIRO Division of Fisheries, Marine Laboratories, PO Box 120, Cleveland, Queensland 4163, Australia
}

\begin{abstract}
To describe the megabenthos communities in the Gulf of Carpentaria, Australia, beam trawls were taken from a systematic grid of 107 stations sampled during November and December 1990. Over 476500 individuals were collected, weighing over $1700 \mathrm{~kg}$ and representing more than 840 species from 150 families. The mean biomass was $15.9 \mathrm{~kg} \mathrm{trawl}^{-1}$, the average number of species was $59.8 \mathrm{trawl}^{-1}$ and the average number of individuals was $4405 \mathrm{trawl}^{-1}$. The main taxa in terms of biomass were spatangoida $(60.5 \%)$, porifera $(13.7 \%)$, zoantharia $(7.3 \%)$, bivalvia $(2.8 \%)$, and decapoda $(2.8 \%)$; they included $12,102,10$ and 198 species respectively. The megabenthos species were mainly scavengers/carnivores (345), suspension-feeders (331), deposit-feeders (121) and a few herbivores (37). Most species were classed as mobile (496) with lesser numbers classed as sessile species (334). Two deposit-feeding spatangoids accounted for $59 \%$ of the biomass but were sampled at only 9 stations. Classification and ordination using species presence or absence data indicated that there were 2 main communities in the Gulf: a community located in predominantly sandy sediments along the eastern and southeastern margins of the Gulf that comprised mainly sessile suspension-feeding sponges, zoantharians, pennatulaceans, bivalve molluscs and ascidians; and a community located in the muddier sediments in the central and western Gulf that comprised mainly deposit-feeding spatangoids and sand dollars. However, sessile suspension-feeders were also found in the central Gulf wherever suitable substrata were present.
\end{abstract}

KEY WORDS: Megabenthos · Gulf of Carpentaria A Australia · Community structure

\section{INTRODUCTION}

The Gulf of Carpentaria, Australia (see Fig. 1), supports a prawn-trawl fishery of over 130 vessels (Pownall 1994) and a developing demersal fish-trawl fishery with 1 licensed vessel (Blaber et al. 1994). The prawntrawlers operate in waters between 10 and $50 \mathrm{~m}$ deep, whereas the fish-trawl fishery is currently restricted to the deeper waters $(>20 \mathrm{~m})$ north of $13^{\circ} 30^{\prime} \mathrm{S}$. South of $13^{\circ} 30^{\prime} \mathrm{S}$, the deeper waters $(>50 \mathrm{~m}$ ) of the central Gulf of Carpentaria have been effectively closed to fishing for $14 \mathrm{yr}$; the seabottom is one of the few in shallow tropical seas that has rarely been trawled. Trawling can have a major impact on epi- and infaunal benthos (Messieh et al. 1991), and since demersal fish-trawling in the central Gulf is likely to expand in the near

\footnotetext{
·E-mail: b.long@qld.ml.csiro.au
}

future, the objective of this study was to describe the benthic communities before the area is trawled.

The megabenthos (benthos sampled by a beam trawl) of the Gulf of Carpentaria has not been described, with the exception of the penaeid prawns (Somers 1994). The only other studies of the continental shelf megabenthos of tropical Australia are of the decapod crustaceans of the North West Shelf off Western Australia (Ward \& Rainer 1988) and the megabenthos of the northern Great Barrier Reef lagoon (Blaber et al. 1993). This study is therefore the first description of non-reefal megabenthos from tropical northern Australia

\section{MATERIALS AND METHODS}

Study area. The Gulf of Carpentaria is a large (approximately $3.7 \times 10^{5} \mathrm{~km}^{2}$ ), shallow (less than $70 \mathrm{~m}$ 


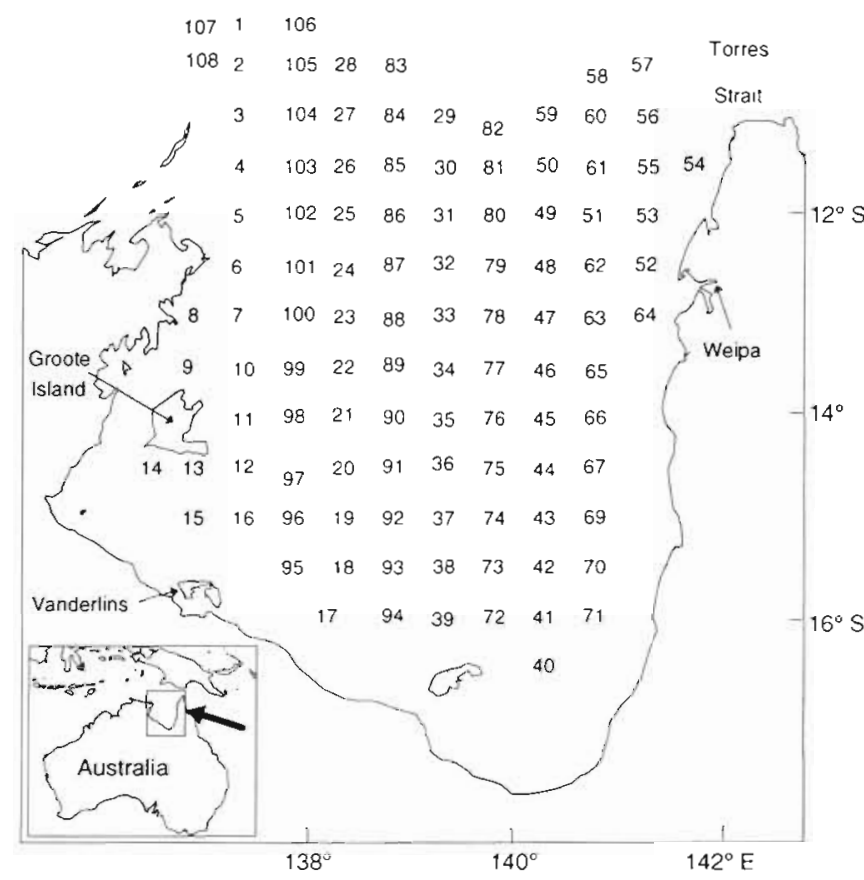

Fig. 1. Gulf of Carpentaria showing FRV 'Southern Surveyor' sampling stations

deep) tropical embayment (Fig. 1). The area has a marked seasonality of rainfall, salinity and temperature which is largely driven by changes in the main wind patterns (Somers \& Long 1994). Most of the rain falls during the northwest monsoons in summer (December to February), with a dry period during the southeast trades (May to October). The salinity of the shallow (to $30 \mathrm{~m}$ ) coastal waters can drop during the wet monsoons from $31-32$ to 20 psu in the surface waters and 27 psu in the bottom waters. For the remainder of the year, salinities are uniform over most of the Gulf at 34 psu. Water temperatures near the coast range from 20 to $30^{\circ} \mathrm{C}$. Surface water temperatures in the central Gulf range from 26 to $30^{\circ} \mathrm{C}$ and bottom water temperatures range from 25 to $28^{\circ} \mathrm{C}$. A boundary layer separates the biological and hydrological processes in the nearshore waters from those in the central Gulf (Wolanski \& Ridd 1990). There is also evidence of a clockwise residual current in the Gulf (Church \& Forbes 1981).

Field sampling. The Gulf of Carpentaria was divided into a $6 \times 6$ nautical mile ( $n$ mile) grid, and from this a systematic grid of 107 sample units $30 \mathrm{n}$ miles apart was selected for sampling (Fig. 1). A station was randomly positioned within each $6 \times 6 \mathrm{n}$ mile sample unit. The position of each station was located with the global positioning system. Stations were sampled from FRV 'Southern Surveyor' between November and December 1990 by towing a $3.0 \mathrm{~m}$ wide by $1.2 \mathrm{~m}$ high beam trawl or 'Church Dredge' rigged with a $30 \mathrm{~mm}$ mesh net bag. Each trawl lasted for 15 min at $6 \mathrm{~km} \mathrm{~h}^{-1}$ from the stern of the ship. Sampling depths ranged between 20 and $63 \mathrm{~m}$. The dredge sampled approximately the top $150 \mathrm{~mm}$ of substratum as well as associated benthos and fish. One sample was taken at each station.

The trawl samples were sorted on board into families and frozen for transport to the laboratory. The large sessile megabenthos, mainly sponges, were sorted immediately after collection, counted and their fresh weight recorded to the nearest $100 \mathrm{~g}$ A small piece of each was frozen and kept for identification.

Samples were identified to species or putative taxon, counted and weighed to the nearest $1 \mathrm{~g}$ by taxonomists at the Queensland Museum, Australia, where the samples were lodged. Colonies rather than individuals were counted and weighed for the colonial animals. The species were also placed into feeding guilds - herbivores, deposit-feeders, scavengers/carnivores and suspension-feeders - by consulting Fauchauld \& Jumars (1979) for polychaetes, Short \& Potter (1987) for molluscs and Barnes (1974) for the remaining phyla. Species were also placed into 3 size classes, large $(>1 \mathrm{~kg}$ ), medium ( 1 to $0.1 \mathrm{~kg}$ ) and small $(<100 \mathrm{~g}$ ), and 2 mobility classes, sessile and mobile.

Sediment samples were collected with a $0.1 \mathrm{~m}^{2}$ Smith-McIntyre grab. Grain sizes were analysed by the method described in McLoughlin \& Young (1985).

Surface-to-bottom salinity and temperature profiles were measured at each station with a Yeokal submersible data logger. Surface, midwater and bottom turbidity samples were collected at each station with Niskin bottles and turbidities were measured with a Hach nephelometer (measured in nephelometric turbidity units, NTU).

Data analysis. The presence or absence of a species rather than biomass or abundance was used for classification and ordination analysis because both plants (seagrass and algae) and solitary and colonial animals were used; this was done to avoid the problematical decision of what constituted an individual. Moreover, in highly heterogeneous communities where the individuals vary greatly in size, as would be expected from a beam trawl, quantitative measures add little useful information to that yielded by a simple species list (Goodall 1978). Species presence or absence data have previously been effective for classification of benthic samples (Field 1970, Moore 1974, Moran 1981) and benthic trawl data (Dyer et al. 1983). The data were analysed by the PATN classification and ordination software (Belbin 1991)

The Bray-Curtis association measure was used to calculate the dissimilarity between stations based on the presence or absence of species (Q-mode analysis). 
When binary data are used the Bray-Curtis measure is equivalent to the Czechanowski measure. Dyer et al. (1983) used the Czechanowski measure to cluster benthic trawl data in the North Sea. The Gower metric was used for calculating the dissimilarity between species based on their presence or absence at stations (R-mode analysis). Station dissimilarities were sorted and the dendrogram was produced by the unweighted pair, group-mean-average (UPGMA) fusion algorithm with a slightly space-dilating value of -0.1. A 2-way table (Belbin 1991) to cross-tabulate the species and station groups was used to assist in interpreting species and station groupings.

A visual summary of the 2-way table was created to show graphically the relationship between the species groups and station groups. To do this the species occurrences in each station group were counted and converted to a percentage of the station group total. The percentages were displayed graphically in a species by station group matrix with 4 grey scales to represent: species absent, 1 to $10 \%, 10$ to $30 \%$ and $>30 \%$ occurrence.

Only species found at more than 2 stations were used for the classification and ordination analysis so as to reduce the number of chance co-occurrences of rare species. Removing rare species has little effect on the outcome of the analysis (Stephenson \& Cook 1980). Station dissimilarities were ordinated by principal coordinate analysis (PCO) rather than multidimensional scaling (MDS) because PCO separates the groups more clearly than MDS (Belbin 1991).

Partial correlation analyses (Pearson's correlation coefficient) were performed for the main taxa, mobility and feeding classes between transformed $\left(\log _{10}+1\right)$ megabenthos biomass ( $\mathrm{kg} \mathrm{trawl} \mathrm{t}^{-1}$ ), abundance (no. trawl ${ }^{-1}$ ) and principal coordinate scores with the abiotic variables, depth, mud, latitude and longitude. This was done to test whether there were Gulf-wide trends in the distribution and abundance of megabenthos which were statistically independent of underlying trends in depth and sediment grain size.

\section{RESULTS}

\section{Abiotic factors}

Water depth was positively correlated with the percentage of mud in the sediment $(r=0.33, p<0.001)$ and negatively correlated with the percentage of sand $(\mathrm{r}=-0.36, \mathrm{p}<0.001)$. Depth was also negatively correlated with the bottom water temperature $(r=-0.64$, $\mathrm{p}<0.001$ ). The bottom water turbidity was positively correlated with the percentage of mud in the sediment $(\mathrm{r}=0.38, \mathrm{p}<0.001)$ and negatively correlated with the percentage of sand $(\mathrm{r}=-0.41, \mathrm{p}<0.001)$. The sandier sediments in the southeast Gulf graded gradually into muds and sandy muds in the northwest Gulf (Fig. 2). There was little evidence of large-scale patterns in turbidity or salinity at the time of sampling. A thermocline was present in the central Gulf at a depth of around $25 \mathrm{~m}$, and surface-water temperatures were 4 degrees higher than bottom temperatures (Somers \& Long 1994).

\section{General}

Approximately 476500 megabenthos weighing $1700 \mathrm{~kg}$ and consisting of 846 species from 150 families were collected from the 107 stations in the Gulf of Carpentaria. A checklist of the taxa collected in the Gulf is given in Long \& Poiner (1994a). The mean biomass was $15.9 \mathrm{~kg} \mathrm{trawl}^{-1}(\mathrm{SE}=5.2)$; the average number of species was 59.8 trawl $^{-1}(\mathrm{SE}=5.8)$; and the average abundance was 4405 ind traw $^{-1}(\mathrm{SE}=2154)$. The dominant taxa in terms of biomass were spatangoids, followed by sponges, zoantharians (mainly solitary, flabellid corals), bivalves and decapods (Table 1). Together these 5 taxa accounted for $87 \%$ of the biomass. The major phyla were well represented: 223 (26\%) were crustacea, 194 (23\%) mollusca, 144 (17\%) echinoder-

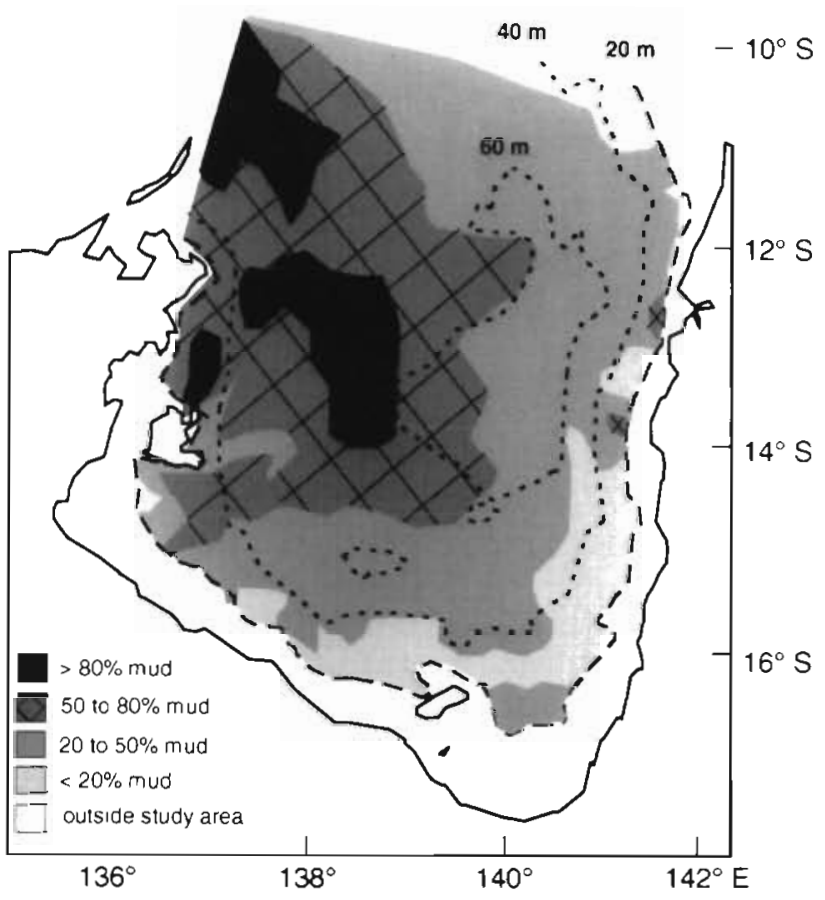

Fig. 2. Sediment grain size, expressed as percentage mud grouped into 4 categories, distribution in the Gulf of Carpentaria, Australia, during November-December 1990. Depth contours (m) overlaid. Map adapted from Somers \& Long (1994) 
Table 1. Total catch, by weight and numbers, of the major classes of benthos, with the number of identified taxa from each class

\begin{tabular}{|lrrr|}
\hline Class & No. taxa & Weight & Numbers \\
\hline Porifera & 102 & 233.10 & 23463 \\
Hydroida & 18 & 7.80 & 6838 \\
Pennatulacea & 9 & 1.96 & 167 \\
Gorgonacea & 7 & 0.36 & 157 \\
Alcyonacea & 19 & 25.18 & 2602 \\
Zoantharia & 10 & 123.61 & 229957 \\
Stomatopoda & 21 & 2.81 & 1821 \\
Decapoda & 198 & 47.05 & 11767 \\
Prosobranchia & 83 & 10.26 & 3897 \\
Cephalaspidea & 2 & 0.13 & 82 \\
Nudibranchia & 15 & 0.47 & 45 \\
Bivalvia & 82 & 48.10 & 6604 \\
Scaphopoda & 2 & 0.12 & 29 \\
Cephalopoda & 10 & 5.78 & 395 \\
Bryozoa & 28 & 28.88 & 10274 \\
Crinoidea & 21 & 8.34 & 1296 \\
Asteroidea & 25 & 24.45 & 888 \\
Spatangoida & 12 & 1031.61 & 146321 \\
Echinoida & 8 & 3.87 & 505 \\
Diadematoida & 1 & 3.65 & 44 \\
Clypeasteroida & 12 & 33.38 & 21409 \\
Holothuroidea & 44 & 26.34 & 548 \\
Ophiuroidea & 28 & 3.96 & 2281 \\
Ascidiacea & 35 & 30.71 & 2112 \\
Miscellaneous & 63 & 2.49 & 3028 \\
Total & 846 & 1704.41 & 476530 \\
\hline
\end{tabular}

mata, $104(12 \%)$ porifera, $63(7 \%)$ coelenterata and 48 $(6 \%)$ polychaeta. Two seagrasses - Halophila spinulosa and Halophila ovalis - and 10 algae were also collected.

Most of the species occurred in low numbers: 411 were represented by less than 10 individuals and 143 by only 1 individual. Most species were also very patchily distributed: 410 species were collected at 1 or 2 stations and of the 303 species that were collected at 1 station, 224 were represented by 5 or fewer individuals and 3 were represented by more than 100 individuals. The most abundant species, Flabellum sp. 3 (123428 individuals), was sampled at only 1 station (40), in the southeast Gulf. Fourteen of the species were widely distributed in the Gulf (Table 2). All of the taxa in this group have an Indo-West Pacific distribution except Bassina calophylla, a bivalve found only in northern Australia and the East Indies (Table 2).

The Gulf megabenthos were mostly scavengers/carnivores (345) and suspension-feeders (331), with fewer deposit-feeders (121) and herbivores (37). Suspension-feeders were the most abundant $(60 \%)$ but deposit-feeders had the highest biomass (64\%). Sponges made up the bulk of the suspension-feeder biomass, and spatangoids made up the bulk of the deposit-feeder biomass. The majority of the Gulf megabenthos were classed as small (791), with medium (34) and large (9) species less prevalent. Most of the species were mobile (496). Sponges (101 species) made up one-third of the sessile species (334).

\section{Distribution of megabenthos in the Gulf}

There were significant correlations between megabenthos abundance and biomass with percentage mud and depth and latitude and longitude (Table 3). However, there were also significant correlations between depth and percentage mud and position in the Gulf (latitude and longitude). Hence partial correlation analyses were necessary. These indicated that the biomass of scavengers/camivores and zoantharians decreased with increasing depth $(p<0.05)$. The biomass of suspension-feeders, sponges, sessile, medium and large-sized megabenthos decreased with increase in percentage mud (Table 3 ). There were significant north-south trends in biomass: the biomass of zoantharians and small megabenthos was higher in the southern Gulf than in the northern Gulf. There were also significant east-west trends: abundance, number of species, and biomass of suspension-feeders, scavenger/carnivores and zoantharians were higher in the eastern Gulf than in the western Gulf (Table 3). Finally, there were significant north-west trends in the biomass of deposit-feeders, spatangoids and mobile megabenthos in the Gulf: all had a higher biomass in the southeast than in the northwest Gulf.

Table 2. Species collected at more than $50 \%$ of the stations in the Gulf of Carpentaria. A: Coelenterata, Alcyonacea; B: Mollusca, Bivalvia; D: Crustacea, Decapoda; O: Echinodermata, Ophiuroidea. n: number of stations sampled

\begin{tabular}{|c|c|c|c|c|}
\hline Species & $\begin{array}{c}\text { Taxonomic } \\
\text { order }\end{array}$ & $\begin{array}{l}\text { Abunda } \\
\text { Mean }\end{array}$ & $\begin{array}{c}\text { nce }\left\{\text { trawl } l^{-1} \text {, }\right. \\
\text { Maximum }\end{array}$ & $n$ \\
\hline Myra biconica & D & 4.8 & 41 & 79 \\
\hline Bassina calophylla & $B$ & 3.1 & 26 & 75 \\
\hline Metapenaeopsis palmensis & is D & 10.0 & 223 & 71 \\
\hline Parthenopus longimanus & $D$ & 3.3 & 22 & 69 \\
\hline Arcania novemspinosa & $\mathrm{D}$ & 2.6 & 27 & 65 \\
\hline Carcinoplax purpurea & $D$ & 2.4 & 18 & 63 \\
\hline Alcyonacea sp. 4 & A & 9.3 & 173 & 63 \\
\hline Phalangipes australiensis & $\mathrm{D}$ & 6.6 & 11 & 61 \\
\hline Ophiuroidea sp. 8 & $\mathrm{O}$ & 9.7 & 182 & 61 \\
\hline Amusium pleuronectes & $\mathrm{B}$ & 5.2 & 123 & 57 \\
\hline Charybdis truncata & $\mathrm{D}$ & 2.3 & 21 & 56 \\
\hline Portunus spinipes & D & 2.7 & 30 & 56 \\
\hline Oratosquilla inornata & $\mathrm{D}$ & 1.5 & 14 & 54 \\
\hline Ceratoplax sp. 1 & $\mathrm{D}$ & 2.5 & 25 & 57 \\
\hline
\end{tabular}


Table 3. Partial correlation analysis of megabenthos species richness (no. species trawl ${ }^{-1}$ ), abundance (no. traw ${ }^{-1}$ ), total biomass

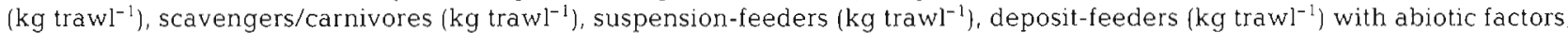
depth $(\mathrm{m})$, percentage mud, latitude, longitude, and latitude $\times$ longitude. Biomass and abundances were $\log _{10}+1$ transformed, and percentage mud was arcsine square-root transformed. $\cdot p<0.05 ; \cdot p<0.001$; ns: not significant

\begin{tabular}{|c|c|c|c|c|c|}
\hline \multirow[t]{2}{*}{ Blological variables } & \multicolumn{5}{|c|}{ Environmental variables } \\
\hline & Depth $(m)^{a}$ & $\% \mathrm{Mud}^{\mathrm{b}}$ & Latitude $^{c}$ & Longitude $^{c}$ & Latitude $\times$ Longitude ${ }^{c}$ \\
\hline Species richness & ns & ns & ns & $0.27 \cdots$ & ns \\
\hline Abundance & ns & ns & ns & $0.21^{\bullet}$ & ns \\
\hline Total biomass & ns & ns & $-0.23^{\circ}$ & ns & ns \\
\hline Scavengers/carnivores & $-0.20^{\circ}$ & ns & ns & $0.25 *$ & ns \\
\hline Suspension-feeders & ns & $-0.26 \cdot$ & ns & $0.25^{\cdots}$ & ns \\
\hline Sessile megabenthos & ns & $-0.27 \cdots$ & ns & $0.25 \cdots$ & ns \\
\hline Mobile megabenthos & ns & ns & ns & ns & $0.20^{\circ}$ \\
\hline Small megabenthos & ns & ns & -0.21 & ns & ns \\
\hline Medium megabenthos & ns & $-0.20^{\bullet}$ & ns & ns & ns \\
\hline Large megabenthos & ns & -0.22 & ns & ns & ns \\
\hline Deposit-feeders & ns & ns & ns & ns & $0.23^{\circ}$ \\
\hline Spatangoida & ns & ns & $-0.19^{\circ}$ & ns & $0.21^{\circ}$ \\
\hline Porifera & ns & $-0.30^{\cdots}$ & ns & ns & ns \\
\hline Zoantharians & ns & ns & $-0.23^{\circ}$ & 0.28 & $-0.48 \cdots$ \\
\hline Bivalvia & $\mathrm{ns}$ & ns & $0.23^{\circ}$ & ns & ns \\
\hline Decapoda & ns & ns & ns & ns & ns \\
\hline \multicolumn{6}{|c|}{ a\% Mud, latitude and longitude partialled out } \\
\hline \multicolumn{6}{|c|}{ "Depth, latitude and longitude partialled out } \\
\hline c\% Mud and depth par & led out of the & on & & & \\
\hline
\end{tabular}

\section{Community structure and distribution patterns}

The similarities between stations characterised by the presence or absence of megabenthos species, as shown in Fig. 3, indicated that there were 2 main station groups at the cut-off level of 1.26 .

Station group A was composed of 28 stations sampled in the central and western Gulf. This group was divided into 3 subgroups (station subgroups 1,2 and 3) at a cut-off level of 0.85 (Fig. 3).

Subgroup 1 stations were in the western Gulf (Fig. 4). There were 45 stations in this subgroup, the largest in station group $\mathrm{A}$. The average biomass, $4.1 \mathrm{~kg}$ traw $]^{-1}$, was mostly made up of deposit-feeders $(3.2 \mathrm{~kg}$ trawl ${ }^{-1}$ ) (mainly spatangoid Maretia planulata and spatangoida sp. 4, and the sand dollar Laganum sp. 1).

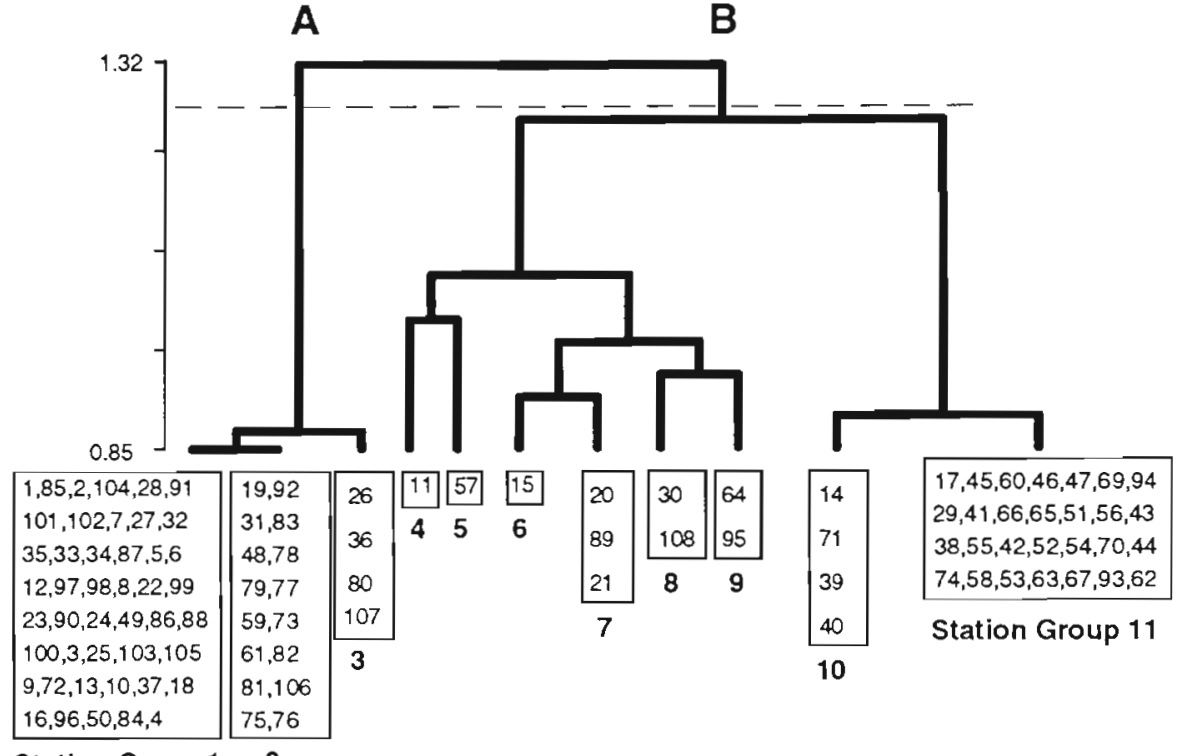

Fig. 3. Dendrogram showing station groups from the classification of the Gulf of Carpentaria beam trawl presence or absence data 


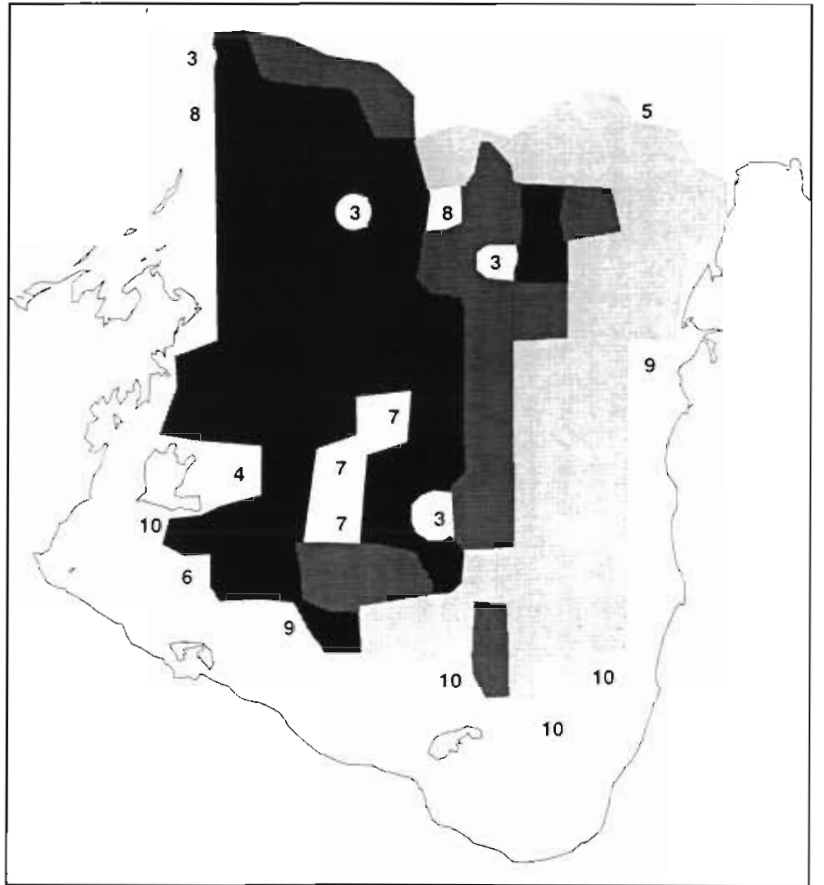

Station group 1 Station group 2

Station group 11

Fig. 4. Station groups formed by the classification of megabenthos presence or absence beam trawl data
The suspension-feeders $\left(0.49 \mathrm{~kg} \mathrm{trawl} l^{-1}\right)$ were mainly bivalve molluscs $\left(0.17 \mathrm{~kg} \mathrm{trawl}^{-1}\right)$ and sponges $(0.11 \mathrm{~kg}$ trawl $\left.{ }^{-1}\right)$. Most of the scavenger/carnivores were decapod crustaceans $\left(0.27 \mathrm{~kg}\right.$ trawl $^{-1}$ ) (Table 4$)$.

Subgroup 2 stations, made up of 16 stations in the central Gulf, had a megabenthos biomass trawl ${ }^{-1}$ similar to subgroup 1 stations, but the average abundance was lower. In contrast, the average number of species trawl $^{-1}$ was higher in the central (subgroup 2) than the western Gulf (subgroup 1). The biomass of subgroup 2 stations consisted mainly of suspension-feeders $(2.8 \mathrm{~kg}$ trawl $l^{-1}$ ), which were predominantly sponges $(1.66 \mathrm{~kg}$ trawl $\left.^{-1}\right)$ and sea pens $\left(0.24 \mathrm{~kg} \mathrm{trawl} l^{-1}\right)$. Depositfeeders, which were less prevalent $\left(0.76 \mathrm{~kg} \mathrm{trawl}^{-1}\right)$, were mainly spatangoids and holothurians $(0.55$ and $0.16 \mathrm{~kg} \mathrm{trawl}^{-1}$ respectively). The scavengers/carnivores $\left(0.63 \mathrm{~kg} \mathrm{traw}^{-1}\right)$ in subgroup 2 stations, as in subgroup 1 stations, were dominated by crustaceans $\left(0.31 \mathrm{~kg} \mathrm{trawl}^{-1}\right)$. Together these 2 subgroups included 61 of the 65 stations in station group A.

The 4 stations in subgroup 3 were scattered throughout the central and western Gulf (Fig. 4). The average biomass was similar to subgroup 2 , with suspensionfeeders dominating (Table 4). In this subgroup, sea pens dominated the suspension-feeders $(0.37 \mathrm{~kg}$ trawl $l^{-1}$ ) whilst holothurians and deposit-feeding bi valves constituted most of the remaining biomass (0.2 and $0.19 \mathrm{~kg} \mathrm{traw}^{-1}$ respectively). As with all the

Table 4. Biological and abiotic characteristics of station groups based on the presence or absence of species at the Gulf of Carpentaria stations. No. of stns: number of stations in each station group; SE: standard error; SD: standard deviation

\begin{tabular}{|c|c|c|c|c|c|c|c|c|c|c|c|}
\hline Station group: & 1 & 2 & 3 & 4 & 5 & 6 & 7 & 8 & 9 & 10 & 11 \\
\hline No. of stns & 45 & 16 & 4 & 1 & 1 & 1 & 3 & 2 & 2 & 4 & 28 \\
\hline $\begin{array}{l}\text { Biomass (kg trawl }{ }^{-1} \text { ) } \\
\text { (SE) }\end{array}$ & $\begin{array}{c}4.1 \\
(11.3)\end{array}$ & $\begin{array}{c}4.2 \\
(3.6)\end{array}$ & $\begin{array}{l}1.4 \\
(1.4)\end{array}$ & $\begin{array}{c}0.01 \\
(-)\end{array}$ & $\begin{array}{c}60.0 \\
(-)\end{array}$ & $\begin{array}{c}168.3 \\
(-)\end{array}$ & $\begin{array}{l}210.1 \\
(251.2)\end{array}$ & $\begin{array}{c}0.15 \\
(0.06)\end{array}$ & $\begin{array}{c}13.2 \\
(18.4)\end{array}$ & $\begin{array}{c}59.2 \\
(55.6)\end{array}$ & $\begin{array}{c}11.9 \\
(19.5)\end{array}$ \\
\hline $\begin{array}{l}\text { Abundance/trawl } \\
\text { (SE) }\end{array}$ & $\begin{array}{l}1517.9 \\
(4726)\end{array}$ & $\begin{array}{l}571.8 \\
(424)\end{array}$ & $\begin{array}{l}228.6 \\
(241)\end{array}$ & $\begin{array}{l}2.0 \\
(-)\end{array}$ & $\begin{array}{c}2592.8 \\
(-)\end{array}$ & $\begin{array}{c}30115.8 \\
(-)\end{array}$ & $\begin{array}{l}19876.2 \\
(98950)\end{array}$ & $\begin{array}{l}46.5 \\
(2.1)\end{array}$ & $\begin{array}{l}275.7 \\
(346)\end{array}$ & $\begin{array}{r}61842.6 \\
(107042)\end{array}$ & $\begin{array}{l}2035.1 \\
(3796)\end{array}$ \\
\hline $\begin{array}{l}\text { Species/trawl }(n) \\
(\mathrm{SE})\end{array}$ & $\begin{array}{c}48.2 \\
(16.0)\end{array}$ & $\begin{array}{c}69.0 \\
(19.8)\end{array}$ & $\begin{array}{l}34.5 \\
(4.8)\end{array}$ & $\begin{array}{l}1.0 \\
(-)\end{array}$ & $\begin{array}{c}47.0 \\
(-)\end{array}$ & $\begin{array}{c}11.0 \\
(-)\end{array}$ & $\begin{array}{l}18.6 \\
(4.0)\end{array}$ & $\begin{array}{l}20.5 \\
(0.7)\end{array}$ & $\begin{array}{l}27.0 \\
(5.7)\end{array}$ & $\begin{array}{l}41.0 \\
(11.0)\end{array}$ & $\begin{array}{c}94.3 \\
(23.4)\end{array}$ \\
\hline $\begin{array}{l}\text { Depth }(\mathrm{m}) \\
\text { (SD) }\end{array}$ & $\begin{array}{l}47.6 \\
(9.1)\end{array}$ & $\begin{array}{l}53.0 \\
(5.7)\end{array}$ & $\begin{array}{l}50.3 \\
(3.9)\end{array}$ & $\begin{array}{c}36.8 \\
(-)\end{array}$ & $\begin{array}{c}29.0 \\
(-)\end{array}$ & $\begin{array}{c}24.2 \\
(-)\end{array}$ & $\begin{array}{l}52.9 \\
(4.0)\end{array}$ & $\begin{array}{l}48.9 \\
(0.7)\end{array}$ & $\begin{array}{l}34.9 \\
(1.4)\end{array}$ & $\begin{array}{l}23.0 \\
(6.0)\end{array}$ & $\begin{array}{c}44.2 \\
(11.2\}\end{array}$ \\
\hline \multicolumn{12}{|l|}{ Substrate } \\
\hline $\begin{array}{l}\text { Sand }(\%) \\
(\mathrm{SD})\end{array}$ & $\begin{array}{l}30 \\
(19)\end{array}$ & $\begin{array}{c}53 \\
(12)\end{array}$ & $\begin{array}{l}37 \\
(15)\end{array}$ & $\begin{array}{l}54 \\
(-)\end{array}$ & $\begin{array}{l}85 \\
(-)\end{array}$ & $\begin{array}{l}55 \\
(-)\end{array}$ & $\begin{array}{c}22 \\
(11)\end{array}$ & $\begin{array}{c}26 \\
(31)\end{array}$ & $\begin{array}{l}67 \\
(4)\end{array}$ & $\begin{array}{l}78 \\
(8)\end{array}$ & $\begin{array}{l}67 \\
(11)\end{array}$ \\
\hline $\begin{array}{l}\text { Mud }(\%) \\
(\mathrm{SD})\end{array}$ & $\begin{array}{l}66 \\
(17)\end{array}$ & $\begin{array}{l}40 \\
(11)\end{array}$ & $\begin{array}{l}57 \\
(18)\end{array}$ & $\begin{array}{l}31 \\
(-)\end{array}$ & $\begin{array}{c}5 \\
(-)\end{array}$ & $\begin{array}{l}41 \\
(-)\end{array}$ & $\begin{array}{l}77 \\
(11)\end{array}$ & $\begin{array}{c}71 \\
(35)\end{array}$ & $\begin{array}{l}26 \\
(5)\end{array}$ & $\begin{array}{c}13 \\
(1.0)\end{array}$ & $\begin{array}{l}25 \\
(10)\end{array}$ \\
\hline $\begin{array}{l}\text { Bottom turbidity (NTU) } \\
\text { (SD) }\end{array}$ & $\begin{array}{c}1.7 \\
(0.73)\end{array}$ & $\begin{array}{l}1.5 \\
(0.52)\end{array}$ & $\begin{array}{l}1.6 \\
(0.52)\end{array}$ & $\begin{array}{l}1.3 \\
(-1\end{array}$ & $\begin{array}{l}1.0 \\
(-)\end{array}$ & $\begin{array}{l}1.2 \\
(-)\end{array}$ & $\begin{array}{l}2.7 \\
(0.26)\end{array}$ & $\begin{array}{c}2.1 \\
(0.84)\end{array}$ & $\begin{array}{c}1.1 \\
(0.57)\end{array}$ & $\begin{array}{c}0.8 \\
10.17\end{array}$ & $\begin{array}{c}1.4 \\
(0.72)\end{array}$ \\
\hline \multicolumn{12}{|l|}{ Mobility } \\
\hline Mobile $\left(\mathrm{kg}\right.$ trawl $\left.\mathrm{l}^{-1}\right)(\%)$ & 94 & 32 & 49 & 0 & 88 & 100 & 100 & 63 & 7 & 56 & 23 \\
\hline Sessile $\left(\mathrm{kg} \mathrm{trawl}^{-1}\right)(\%)$ & 6 & 68 & 51 & 0 & 12 & 0 & 0 & 37 & 93 & 44 & 77 \\
\hline \multicolumn{12}{|l|}{ Feeding mode } \\
\hline Suspension $\left(\mathrm{kg} \operatorname{trawl}^{-1}\right)(\%)$ & 12 & 67 & 67 & 0 & 61 & 0 & 0 & 52 & 93 & 45 & 81 \\
\hline Carnivore $\left(\mathrm{kg} \mathrm{trawl}^{-1}\right)(\%)$ & 9 & 15 & 15 & 100 & 23 & 0 & 0 & 36 & 1 & 2 & 13 \\
\hline Deposit $\left(\mathrm{kg} \mathrm{trawl}^{-1}\right)(\%)$ & 78 & 18 & 18 & 0 & 16 & 100 & 100 & 12 & 6 & 53 & 4 \\
\hline Herbivore $\left.(\mathrm{kg} \mathrm{traw})^{-1}\right)(\%)$ & 1 & 0 & 0 & 0 & 0 & 0 & 0 & 0 & 0 & 0 & 2 \\
\hline
\end{tabular}


subgroups in station group A, crustaceans dominated the scavengers/carnivores $\left(0.2 \mathrm{~kg} \mathrm{trawl}^{-1}\right)$.

Station group $B$ was the largest, with 79 stations. It was divided into 8 subgroups (station subgroups 4 to 11) at a cut-of level of 1.00

Subgroup 4, a single station (11) $50 \mathrm{~km}$ east of Groote Island, had the lowest biomass $\left(<1 \mathrm{~kg} \mathrm{trawl}^{-1}\right)$. Scavenging/carnivorous crustaceans were the only species taken with the beam trawl (Table 4).

Subgroup 5, a single station (57) near the western approach to Torres Strait, had a rich seagrass and algal bed flora and megabenthos fauna (Table 4). Numerous large sea cucumbers, the pearl oyster Pinctada sugillata, the green algae Caulerpa mexicana and C. racemosa and the seagrass Halophila spinulosa dominated the $60 \mathrm{~kg} \mathrm{trawl^{-1 }}$ taken there. The biomass was relatively evenly distributed among the feeding categories: suspension-feeders were mostly $P$. sugillata (28.04 kg trawl ${ }^{-1}$ ); carnivorous asteroids were also important $\left(12.32 \mathrm{~kg} \mathrm{trawl}{ }^{-1}\right)$, as were depositfeeding holothurians $\left(9.16 \mathrm{~kg}\right.$ trawl $\left.{ }^{-2}\right)$.

At subgroup 6, a single station (15) south of Groote Island in shallow water with muddy sand sediments, large numbers of spatangoid sp. 4 were the main megabenthos (167.61 kg trawl-1) (Table 4).

Subgroup 7 was made up of 3 adjacent stations in the sandy muds of the central Gulf. This subgroup had the highest average biomass $\left(207.6 \mathrm{~kg} \mathrm{trawl^{-1 }}\right)$ due to the relatively large size and high abundances (19574 trawl $^{-1}$ ) of spatangoid sp. 4 collected at Stns 20 and 89

Subgroup 8 (Stns 107 and 30) in the northern Gulf had low biomass $\left(0.15 \mathrm{~kg}\right.$ trawl $\left.{ }^{-1}\right)$ and abundance (46.5 trawl $\left.^{-1}\right)$. The fauna there were mostly decapod crustaceans.

Subgroup 9 was made up of 2 sandy stations Stn 64 off Weipa in the eastern Gulf and Stn 17 over $500 \mathrm{~km}$ away in the southern Gulf. The megabenthos in this subgroup were mainly large sponges (Table 4).

Subgroup 10 was a group of 3 stations (39, 40 and 71) east and north of the Vanderlin Islands, and a single station (14) south of Groote Island. The average biomass was high due to the large numbers of depositfeeding spatangoids (4643 trawl $^{-1}, 25.49 \mathrm{~kg} \mathrm{trawl}^{-1}$ ) and suspension-feeding ascidians (56679 trawl $^{-1}$, $31.27 \mathrm{~kg} \mathrm{trawl}^{-1}$ ), the latter distinguishing this subgroup from other dominated by spatangoids. The spatangoids and ascidians were responsible for the high proportion of deposit-and suspension-feeders in this group (Table 4 ).

The biomass at subgroup 11, a large subgroup of 28 stations along the eastern Gulf (Fig. 5), was dominated by suspension-feeders $\left(9.6 \mathrm{~kg}\right.$ trawl $\left.{ }^{-1}\right)$, chiefly sponges $\left(6.07 \mathrm{~kg} \mathrm{trawl}^{-1}\right)$, zoantharians $\left(0.74 \mathrm{~kg} \mathrm{trawl}^{-1}\right)$, sea pens $\left(0.61 \mathrm{~kg} \mathrm{trawl}^{-1}\right)$ and bivalve molluscs $(0.29 \mathrm{~kg}$

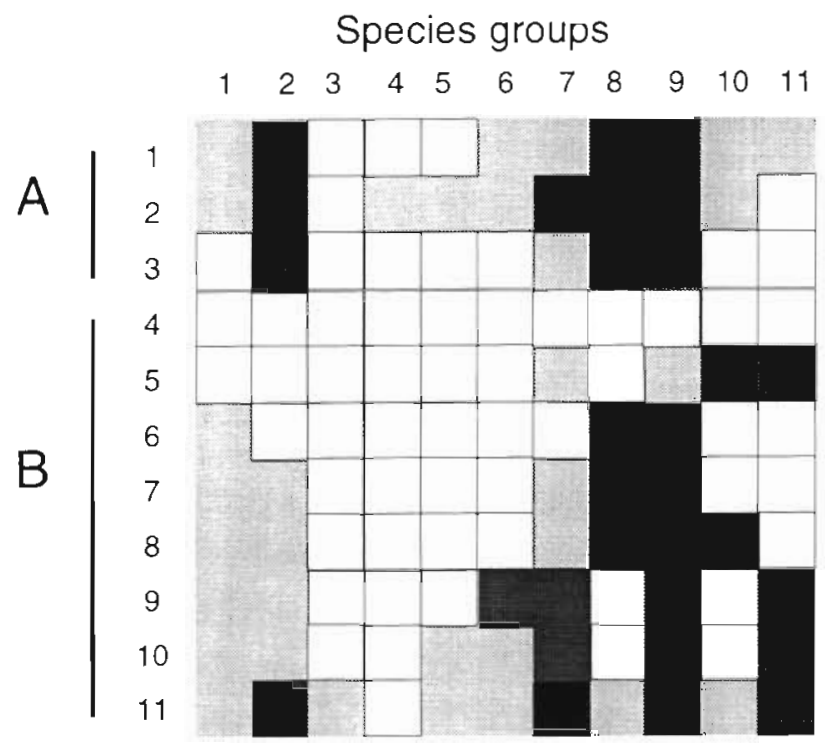

Fig. 5. Distribution of megabenthos species groups 1 to 11 in relation to station groups $A$ (subgroups 1 to 3 ) and $B$ (subgroups 4 to 11) in the Gulf of Carpentaria. Species and station groups are presented as a 2 -way table with the frequency of occurrence of species in a station group displayed as: $(\square)$ species absent; (圈) 1 to $10 \%$; 10 to $30 \%$; (口) $>30 \%$

trawl $\left.l^{-1}\right)$. The scavenger/carnivores $\left(1.6 \mathrm{~kg} \mathrm{trawl}^{-1}\right)$ were dominated by crustaceans $\left(0.88 \mathrm{~kg} \mathrm{trawl}^{-1}\right)$.

These 11 subgroups fell into 2 broad categories. The first was station group $\mathrm{A}$, made up of stations in the muddy sediments ( $\bar{x}=59 \%$ mud) of the central and western Gulf, with an average water depth of $48 \mathrm{~m}$. The megabenthos here were mostly deposit-feeders. However, 2 of the subgroups ( 2 and 3 ) had mostly sessile suspension-feeders, so the stations in these 2 subgroups represented transition areas between the megabenthos community in coarser sediments in the eastern and southeastern Gulf and the community in the western Gulf.

The other broad category, station group B, included stations that were mostly along the southern and eastern margins of the Gulf in shallow water $(\bar{x}=41.6 \mathrm{~m})$ and coarse sediments ( $\bar{x}=32 \%$ mud). The megabenthos at these stations were mainly sessile suspensionfeeders. There were also a number of subgroups (4 to 9) within this broad category that were mostly singlestation groups with mixed species assemblages and a mixture of sediment types.

\section{Species groups}

On the basis of their presence or absence at sites, the megabenthos were separated into 11 groups at a dis- 
similarity measure of 1.27 (dendrogram not shown). Below this level there were many small and apparently biologically meaningless groups, and above this level much information would be lost. The species and station groups were arranged in a 2 -way matrix to visually summarise the relationship between them (Fig. 5).

Group 1 consisted of 30 species with patchy distributions, which were collected throughout the Gulf (Fig. 5). The species in this group were mainly suspension-feeders (19 species): porifera ( 8 species), ascidiacea (4 species), coelenterata (4 species), serpulida (Filograna sp.), bivalvia (Minnivola sp. nov.), and crinoidea (1 species). The 5 deposit-feeders were spatangoids ( 3 species), holothurians (Acaudina sp.) and the mollusc Tellina donaciformis. This group included spatangoida sp. 4, which was collected at only 4 stations but was the dominant taxon in the Gulf in terms of biomass. The 6 scavengers/carnivores were decapods (4 species) and asteroids ( 2 species). Each species in this group was collected at between 2 and 9 stations ( $\overline{\mathrm{x}}=3.6$ stations $)$.

Group 2 was composed of species that were 'common' in the Gulf (Fig. 5). This group had close to the same number of species as Group 1 (37 species) and a similar breakdown by feeding type, with suspensionfeeders dominating (24 species) followed by scavengers/carnivores $(7$ species $)$ and deposit-feeders (5 species). This group included the herbivorous sea urchin Chaetodiadema granulatum. The taxonomic composition was also similar ( 10 echinodermata, 7 porifera, 5 ascidiacea and 4 hydroida)

Group 3 (bryozoan sp. 16, asteroid sp. 4 and crinoid sp. 7), Group 4 (alcyonacea sp. 18 and sponge sp. 82) and Group 5 (sponge spp. 7,94 and 95) contained rare species. With the exception of asteroid sp. 4 , all species in these 3 species groups were suspension-feeding sponges, crinoids, bryozoans or alcyonarians.

With the exception of bryozoan sp. 12 and poriferan sp. 25, Group 6 had 9 species, which were collected at station subgroup 10 along the eastern Gulf and station subgroup 8. Half (5) were sessile, hard substratum dwellers. Of the 9 species, 6 were suspension-feeders and the remainder were scavengers/ carnivores.

Group 7 was made up of 80 species that were found mainly along the eastern and southeastern margins of the Gulf; however, many were also common in the central Gulf (Fig. 5). They were mostly suspension-feeders (41), with bryozoans (10 species), coelenterates (10 species) and sponges (14 species) well represented. The 25 species of scavengers/carnivores in this group were mainly mobile crustaceans (15 species) and the carnivorous starfish Luidia maculata. Deposit-feeders were represented by 11 species, of which 7 species were echinodermata. Three herbivores were also pre- sent: the sea urchins Echinoida spp. 2 and 3 and the gastropod Strombus vittatus. The major phyla were evenly represented (10 bryozoa, 10 coelenterata, 15 crustacea, 15 echinodermata, 13 mollusca, 14 porifera).

Most of the species (70) were small $(<100 \mathrm{~g})$ except for 7 sponges, 2 holothurians (Holothuria ocellata and H. pervicax), 1 starfish (Luidia maculata) and 1 bivalve (Malleus albus). Of these, only $H$. ocellata and sponge sp. 55 were over $1 \mathrm{~kg}$.

The species that characterised this group included 13 porifera; the bryozoans Triphyllozoon sp., Adeonellopsis sp. Scrupocellaria sp., Adeonellopsis sp. and bryozoa spp. 2 and 3; the coelenterate Hydroida sp. 8; the small anemone-like Sphaenopus marsupialis (found at 13 stations); 3 species of the solitary scleractinian coral Flabellum spp.; and 3 species of alcyonaceans (spp. 1, 5 and 11). Also present in this group was the venerid bivalve mollusc Antigonia lamellaris. There were 6 gastropods: the carrier shells Xennophora indica and $X$. solarioides; the frog shell Bursa rana; the triton shell Distorsio reticularis; the muricid shell Chicoreus cervicornis; and the stromb Strombus vittatus. There was also 1 octopus: octopoda sp. 1. Brachyuran crabs were well represented: decorator crabs Hyastenus sp. 1, elbow crabs Parthenopus longispinus and $P$. hoplonotus were common as were the leucosid crabs Myra mammilaris, Leucosia whitei and $L$. ocellata. Hermit crabs represented were Spiropagurus sp. 3 and Diogenes sp. 1, while swimming crabs included Portunus granulatus, P. gracilimanus and Lupocyclus rotundatus. There were also 2 prawns: the penaeids Solenocera pectinata and Trachypenaeus granulosus. Echinodermata included the starfish Metrodira subulata, Stellaster equestris and Luidia maculata; 2 species of sand dollars (Laganum spp. 2 and 3); 2 ophiuroids (spp. 1 and 6); and 2 holothurians (Holothuria pervicax and $H$. ocellata). The ascidians present were Hypodistoma deerratum, Polycarpa chinensis and Phallusia millari.

Group 8 consisted of 7 species found in the muddier sediments of the central and western Gulf, and were also common in the transition areas between the central and eastern Gulf (station groups 6, 7 and 8). The sand dollar Laganum sp. 1 was the dominant species in this group in terms of abundance and biomass. The other species in the group were the bivalves Cultellus cultellus, Corbula scaphoides and Dosinia mira; the crabs Arcania septemspinosa and Ceratoplax sp. 2 ; and asteroidea sp. 1

Group 9 species were very common throughout the Gulf. Many also had broad, Indo-West Pacific geographical ranges. Nearly half (16 species) of the species in this group were small, mobile crustaceans, mainly decapods. Fourteen of these species were collected at more than $50 \%$ of the stations (Table 2). 
Group 10 was a suite of species that were mostly collected at Stn 57 near the western entrance to Torres Strait. This species group represented the shallowwater megabenthos of the seagrass and algae beds of western Torres Strait. The biomass consisted mainly of algae (Caulerpa mexicana and C. racemosa), seagrass (Halophila spinulosa) and 3 large holothurians (Bohadschia marmorata, Holothuria scabra and Stichopus horrens). The pearl shell Pinctada sugillata was also abundant .

Group 11 was an assemblage of species found mainly at $\operatorname{Stn} 70$ in the shallow inshore waters of the southeastern Gulf of Carpentaria. This species group included the commercially fished prawn Penaeus esculentus.

The 11 species groups and 2 main station groups defined a coastal zone along the eastern and southeastern margins of the Gulf with sandy ( $\bar{x}=62 \%$ sand) sediments and a megabenthos with a comparatively high abundance (9240 ind trawl $^{-1}$ ) and biomass $\left(33.9 \mathrm{~kg} \mathrm{trawl}{ }^{-1}\right)$. Suspension-feeders dominated in terms of biomass $\left(10.1 \mathrm{~kg} \mathrm{trawl}^{-1}\right.$ after excluding the large hauls of spatangoida sp. 4 from Stns 20 and 89 in station subgroup 7), with sponges, alcyonarians, zoantharians and ascidians comprising most of the suspension-feeder biomass.

The central-western Gulf zone, in contrast, had muddier sediments ( $\bar{x}=59 \%$ mud), low abundance (1200 ind. trawl $\left.l^{-1}\right)$ and low biomass $\left(4.0 \mathrm{~kg} \mathrm{trawl}^{-1}\right)$. Deposit-feeders rather than suspension-feeders dominated in this region. However, sessile suspension-feeders (sponges, pennatulaceans, hydroids, zoantharians and ascidians) were found in both the coastal and the central-western zones wherever hard substrate was present.

Species richness was higher in the coastal zone (70 species trawl $\left.{ }^{-1}, \mathrm{SE}=5.9\right)$ than in the centralwestern Gulf zone (52 species trawl ${ }^{-1}, \mathrm{SE}=2.4$ ), due to a significant east-west trend in species richness across the Gulf. The proportion of the catch that was scavengers/carnivores was similar in the coastal and the central-western zones. There were few herbivorous species, and their biomass and abundance were both low.

\section{Community structure parameters in relation to abiotic parameters}

The 2 main station groups - A and B - were well separated along the first 2 axes from the principal coordinate analysis of the species presence or absence data (Fig. 6). Partial correlation analysis of the 3 principal coordinates (PCO 1 to $\mathrm{PCO} 3$ ) with depth, percentage mud, latitude and longitude indicated that depth, per-

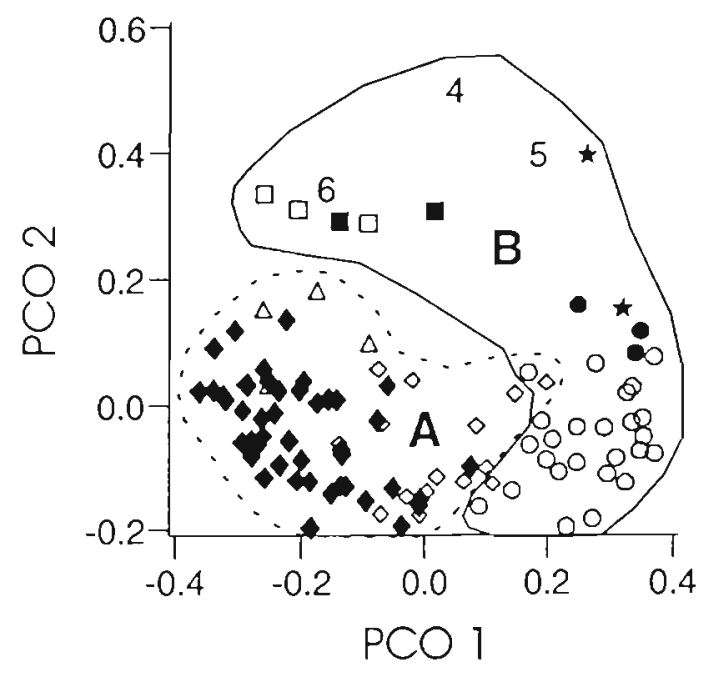

Fig. 6. Plots of axes 1 and 2 of the principal coordinates analysis of 107 stations, based on species presence or absence, showing main group A, composed of $(\$)$ subgroup $1,(0)$ subgroup 2 , and $(\Delta)$ subgroup 3 , and main group $B$, composed of numbered subgroups 4,5 and 6 , (प) subgroup $7,(\square)$ subgroup 8 , ( subgroup $9,(0)$ subgroup 1 , and (1) subgroup 11

centage mud and longitude correlated significantly with the first principal coordinate (Table 5). Thus the first principal coordinate represented an axis related to changes in species composition with respect to depth, percentage mud and east-west trends across the Gulf. In contrast, PCO 2 measured changes in species composition that were related to depth, or factors associated with depth only. The third principal component (PCO 3) measured changes in species composition with depth and with changes in a north-south and a southeast-northwest direction. Thus there were significant changes in species assemblages in the Gulf which were correlated with depth and sediment grain size. Moreover, when depth and sediment were statistically controlled in the correlation analysis, there were significant changes in species assemblages across (east-west) and down (north-south) the Gulf.

\section{DISCUSSION}

There were 2 well-defined megabenthos communities in the Gulf of Carpentaria: an eastern-southeastern coastal community (station group B) and a centralwestern Gulf community (station group A).

The existence in the Gulf of 2 distinct zones has also been observed for phytoplankton (Rothlisberg et al. 1994) and demersal fish (Blaber et al. 1994), but the zonation was not always clear-cut for some taxocenes: the distribution and abundance of macrobenthic infauna was mainly correlated with sediment grain 
Table 5. Partial correlation analysis of principal coordinate scores 1 to 3 (PCO 1 to PCO 3) from the ordination of station presence or absence data, with depth (m), percentage mud (\%Mud), latitude, longitude and latitude $\times$ longitude. \%Mud was arcsine square-root transformed. $\mathrm{p}<0.05 ; \cdots p<0.01$ : ns: not significant

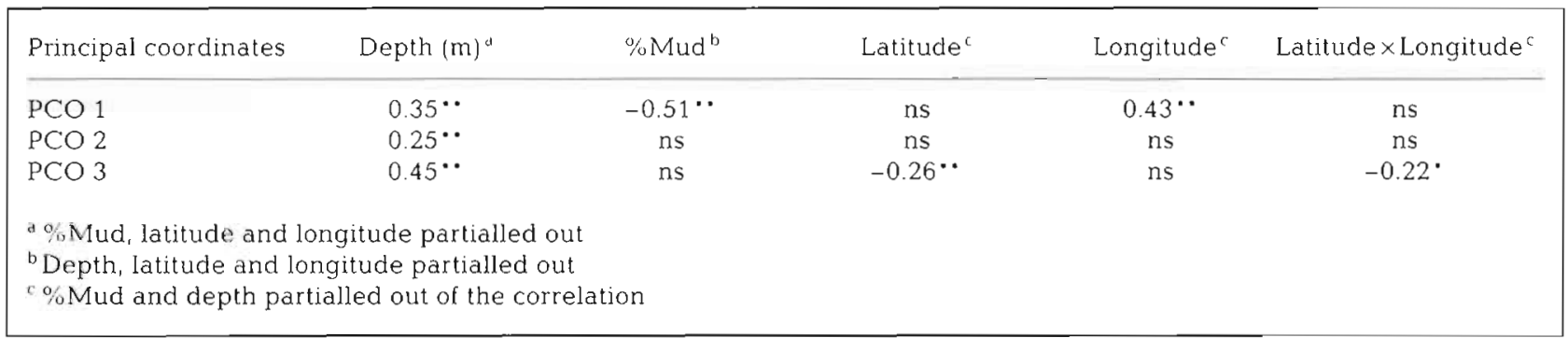

size and depth (Long \& Poiner 1994b), and the numerically dominant squids and cephalopods in the Gulf did not show any clearly preferred depth range (Dunning et al. 1994).

The 2 main station groups were each divisible into at least 1 large subgroup that characterised the group and several small subgroups with distinctive megabenthos and sediment types. The smaller subgroups were mainly scattered along the nearshore margins of the Gulf or situated between the large subgroups and represented transition areas in the Gulf.

The distribution of the numerically dominant Gulf megabenthos was correlated with sediment type, depth and geographic position in the Gulf. Sediment grain size and depth were also significant factors correlated with the distribution of commercial prawns in the Gulf (Somers 1994), and the megabenthos off the west coast of Africa (Longhurst 1958), Israel (Gilat 1964), False Bay, South Africa (Field 1970) and the Northumberland coast, England (Buchanan 1963). In this study, however, there were also significant spatial trends within the Gulf (east-west, north-south and southeast-northwest) that were statistically independent of depth and sediment grain size.

The spatial trends in megabenthos abundance, biomass and species richness in the Gulf may be explained by the pattern and nature of the water circulation, which is linked to sediment distribution, coupled with the climate. The surface-water salinities in the coastal regions ( $<30 \mathrm{~m}$ depth) may be reduced to 20 psu during the wet monsoon by freshwater input from a $1200000 \mathrm{~km}^{2}$ water catchment basin that empties via rivers into the southeast and southern Gulf (Torgersen et al. 1983). Moreover, the coastal waters (10 to $20 \mathrm{~km}$ offshore) are apparently largely independent of the central Gulf waters due to a coastal water boundary layer that traps freshwater runoff, nutrients and suspended sediments (Wolanski \& Ridd 1990), which may partly explain why the waters of the central Gulf are biologically independent of the coastal boundary layer (Rothlisberg et al, 1994). Furthermore, oxygen and temperature in the water column become stratified in the central Gulf over spring and summer and oxygen levels below $1.5 \mathrm{ml}^{-1}$ have been recorded in the bottom waters of the central Gulf during summer (Forbes 1984). Dyer et al. (1983) considered that substratum type, water masses and their associated plankton, depth, temperature range and circulation patterns were important factors which interacted in complex ways to affect the distribution patterns of the megabenthos within the North Sea.

Storm and cyclonic disturbances may also affect the distribution of the Gulf megabenthos; an average of 2 cyclones pass through the Gulf every year (Lourensz 1981) and wave surge from a cyclone can disturb the sediments on the seabed down to $30 \mathrm{~m}$ (Kirby-Smith \& Ustach 1986). Furthermore, benthos down to $40 \mathrm{~m}$ may be affected by waves (Hall 1994).

\section{Comparisons with other studies}

The main factors that govern the abundance of sessile megabenthos in the Gulf of Carpentaria appear to be the amount of substratum suitable for sessile megabenthos to attach to, and possibly the quality and quantity of food in the water column. Sponges, zoantharians, alcyonarians and ascidians were characteristic and often dominant features of coarse sediments in the eastern and southeastern coastal zones of the Gulf. The coastal zone has high phytoplankton production equal to that of upwelling areas on continental shelves (Rothlisberg et aI. 1994). In contrast, there were few sessile megabenthos in the muddy sediments of the central and western Gulf. Pennatulaceans were the most common sessiles in the soft sediments, and sponges were present when the substratum was suitable; however, neither group was abundant.

The link between substrate and sessile megabenthos may be a general feature of continental shelves. Sponges, alcyonarians and gorgonians were the dominant sessile megabenthos in the coarse sediments of 
the North West Shelf off Western Australia (Sainsbury 1987). In contrast, there was little sessile megabenthos in the pelagic carbonate muds on the Scott Reef-Rowley Shoals platform off northwest Australia (McLoughlin et al. 1988). Sponges, ascidians, alcyonarians and hydroids were abundant in the coarse sediments of the deeper $(50$ to $70 \mathrm{~m})$ waters of the northern Great Barrier Reef lagoon, and the shallow banks (15 to $20 \mathrm{~m}$ ) were dominated by the bivalve Pinctada spp. and macroalgae, mainly Caulerpa spp. (Blaber et al. 1993). In contrast, there were few sessile megabenthos in the muddy inshore areas.

If the availability of suitable substrate is a main factor, one would expect that, on a global scale, there would be a latitudinal gradient in the standing biomass of sessile megabenthos that correlates with the increase in rock and gravel on the continental shelves with increase in latitude (Hayes 1967). This simple relationship would be locally modified by the presence of niches, rugosity, patchiness and heterogeneity of the substrate, quality and quantity of food, and regionally by the presence or absence of upwelling.

The relationship between standing biomass, turnover rate and water temperature must also be considered. There is evidence that the standing biomass of sessile megabenthos is high at high latitudes: in some areas of the Ross Sea, Antarctica, with upwelling, high productivity and large numbers of ice-rafted rocks and boulders, the megabenthos forms a dense and continuous bed of sessile sponges, ascidians and bryozoans (Bullivant 1967). At Point Barrow, Alaska, the megafauna taken by dredge in the deeper water in areas of rubble was dominated by ascidians and sponges (MacGinitie 1955). On the plateau of the grand banks off Newfoundland-Labrador, Canada, which has high primary productivity and abundant ice-rafted boulders and stones, a dense sessile megabenthos of porifera and mussels was trawled (Nesis 1970). This may partly explain Tseythin's (1987) findings that the biomass of megafauna in cold-water regions was greater than that in warm-water regions by a factor of 20 .

The species richness of the sessile megabenthos was moderately high in the warm waters of the Gulf of Carpentaria (102 porifera, 35 ascidiacea and 28 bryozoa) and the northern Great Barrier Reef lagoon (64 sponges, 48 ascidians and 24 bryozoans; Blaber et al. 1993). Species richness, however, was higher in the Antarctic where 294 porifera, 92 ascidiacea and 321 bryozoa were collected mostly by trawl or dredge (Dell 1972). The extraordinarily high numbers of species have been attributed to the extremely wide circumpolar distribution of many species (Arntz et al. 1994).

The mobile megabenthos in the Gulf of Carpentaria was dominated by decapod crustaceans. The number of species of decapods collected by dredges or trawls in the Gulf of Carpentaria (198) was close to the number in the South Atlantic Bight (184 species; Wenner \& Read 1982), less than on the North West Shelf of western Australia (308 species; Ward \& Rainer 1988) and higher than off tropical West Africa (143 species; Longhurst 1958), in the northern Great Barrier Reef lagoon (108 species; Blaber et al. 1993), the Bering Sea (24 species; Neyman 1960), the North Sea (18 species; Holme 1966), Scottish lochs (5 species; McIntyre 1956) and Antarctica (2 species; Dell 1972).

Over 840 species of megabenthos were recorded in the Gulf of Carpentaria trawl samples. In a similar study of the megabenthos of the northern Great Barrier Reef lagoon, more than 600 species were recorded from 100 beam trawls (Blaber et al. 1993). In contrast, only 200 species were identified from 60 beam trawls taken in the Bering Sea in a study area approximately $550000 \mathrm{~km}^{2}$ (Neyman 1960), although the Bering Sea is an area of high primary and secondary production with a large benthic standing biomass (McRoy et al. 1972, Alton 1974).

The results of the above species-richness comparisons must necessarily be interpreted cautiously. However, they indicate that the relationship between megabenthos abundance and species richness, and geographical location and environmental factors is complex; there may not be a simple link between species richness and latitudinal gradients in the subtidal marine environment (see Longhurst \& Pauly 1987 Alongi 1990).

The megabenthos species that were widely distributed in the Gulf of Carpentaria were also widely distributed throughout the Indo-West Pacific. Blaber et al. (1994) found that the numerically dominant and widespread fish species in the Gulf were also characteristic of shallow $(<80 \mathrm{~m})$, soft-bottom trawl grounds throughout the Indo-West Pacific region. Similarly, Dunning et al. (1994) found that many of the demersal cephalopods of the Gulf of Carpentaria had an Indo-West Pacific distribution. The results for the megabenthos conform with the consensus that the dominant marine fauna in the Gulf of Carpentaria is part of a wider IndoWest Pacific fauna.

Acknowledgements. We are grateful for the assistance of all participants in Cruise SS03/90 of FRV 'Southern Surveyor' The work was partly funded by FIRDC grants $88 / 77$ and $90 / 29$. Special thanks to S. Blaber, D. Brewer and 2 external reviewers for their constructive comments and suggestions.

\section{LITERATURE CITED}

Alongi DM (1990) The ecology of tropical soft-bottom benthic ecosystems. Oceanogr mar Biol A Rev 28:381-496 
Alton MS (1974) Bering Sea benthos as a food resource for demersal fish populations. In: Hood DW, Kelly EJ (eds) Oceanography of the Bering Sea. Institute of Marine Science, University of Alaska, Fairbanks, p 257-277

Arntz WE, Brey T, Gallardo VA (1994) Antarctic benthos. Oceanogr mar Biol A Rev 32:241-304

Barnes RD (1974) Invertebrate zoology. WB Saunders, Philadelphia

Belbin L (1991) PATN technical reference. CSIRO Division of Wildlife and Ecology, Canberra

Blaber SJM, Brewer DT, Caeser D, Connell M, Dennis D, Glaister J, Gribble N, Hill BJ, Long B, Milton DA, Pitcher R, Poiner IR. Salini J, Thomas M, Veronise S, Wang Y, Wassenberg $I$ (1993) The effects of prawn trawling in the far northern section of the Great Barrier Reef: final report to GBRMPA on 1991-92 research. CSIRO Division of Fisheries Unpublished Report, June 1993. Queensland

Blaber SJM, Brewer DT, Harris AN (1994) Distribution, biomass and community structure of demersal fishes of the Gulf of Carpentaria, Australia. Aust J mar Freshwat Res 45:375-396

Buchanan JB (1963) The bottom fauna communities and their sediment relationships off the coast of Northumberland. Oikos 14:154-175

Bullivant JS (1967) Ecology of the Ross Sea benthos. NZ Dep sci ind Res Bull 176:49-75

Church JA, Forbes AMG (1981) Non linear model of the tides in the Gulf of Carpentaria. Aust J mar Freshwat Res 32 $685-697$

Dell RK (1972) Antarctic benthos. Adv mar Biol 10:2-216

Dunning $M$, McKinnon S, Lu CC, Yeatman J, Cameron D (1994) Demersal cephalopods of the Gulf of Carpentaria, Australiá. Aust J mar Freshwat Res 45:351-374

Dyer MF, Fry WG, Cranmer GJ (1983) Benthic regions within the North Sea. J mar biol Ass UK 63:683-693

Fauchauld K, Jumars PA (1979) The diet of worms: a study of polychaete feeding guilds. Oceanogr mar Biol A Rev 17 $193-284$

Field JG (1970) The use of numerical methods to determine benthic distribution patterns from dredgings in False Bay Trans R Soc S Afr 39:183-200

Forbes AMG (1984) The contribution of local processes to seasonal hydrology of the Gulf of Carpentaria. Oceanogr trop 19:193-201

Gilat E (1964) The macrobenthic invertebrate communities on the Mediterranean continental shelf of Israel. Bull Inst océanogr Monaco 62(1290):46

Goodall DW (1978) Sample similarity and species correlation In: Whittaker RH (ed) Ordination of plant communities. W Junk, The Hague, p 99-149

Hall SJ (1994) Physical disturbance and marine benthic communities: life in unconsolidated sediments. Oceanogr mar Biol A Rev 32:179-239

Hayes MO (1967) Relationships between coastal climate and bottom sediment type of the inner continental shelf. Mar Geol 5:111-132

Holme NA (1966) The bottom fauna of the English Channel. Part II. J mar biol Ass UK 46:401-493

Küby-Smith WW, Ustach J (1986) Resistance to hurricane disturbance of an epifaunal community on the continental shelf off North Carolina. Estuar coast Shelf Sci 23:433-442

Long BG, Poiner IR (1994a) A checklist of megabenthos recorded in the Guif of Carpentaria, November-December 1990. CSIRO mar Lab Rep No 219, Hobart, Australia, p 1-33

Long BG, Poiner IR (1994b) Infaunal benthic community structure and function of the Gulf of Carpentaria, northern Australia. Aust J mar Freshwat Res 45:293-316
Longhurst AR (1958) An ecological survey of the West African marine benthos. Fish Publ Col Off 11:1-102

Longhurst AR, Pauly D (1987) Ecology of tropical oceans. ICLARM contribution no 389, Academic Press, New York

Lourensz RS (1981) Tropical cyclones in the Australian region July 1909 to June 1980. Australian Bureau of Meteorology, Australian Government Publishing Service, Canberra

MacGinitie GE (1955) Distribution and ecology of the marine invertebrate off Point Barrow, Alaska. Smithson misc Collns 128:1-201

McIntyre AD (1956) The use of trawl, grab and camera in estimating marine benthos. J mar biol Ass UK 35:419-429

McLoughlin RJ, Davis TLO, Ward TJ (1988) Sedimentary provinces and associated bedforms and benthos on the Scott Reef-Rowley Shoals platform off northwest Australia. Aust J mar Freshwat Res 39:133-144

McLoughlin RJ, Young PC (1985) Sedimentary provinces of the fishing grounds of the north west shelf of Australia: grain-size frequency analysis of surficial sediments. Aust $J$ mar Freshwat Res 36:671-681

McRoy CP, Goering J, Shiels W (1972) Studies in primary productivity in the eastern Bering Sea. In: Takenouti A (ed) Biological oceanography of the northern north Pacific Ocean. Motoda Commemorative Volume. Idemitsu Shoten, Tokyo, p 199-216

Messieh SN, Rowell TW, Peer DL, Cranford PJ (1991) The effects of trawling, dredging and ocean dumping on the eastern Canadian continental shelf seabed. Cont Shelf Res $11: 1237-1263$

Moore PG (1974) The kelp fauna of northeast Britain. IlI. Qualitative and quantitative ordinations, and the utility of a multivariate approach. J exp mar Biol Ecol 16:257-300

Moran PJ (1981) Use of numerical and binary data in classification of marine fouling communities. Aust J mar Freshwat Res 32:805-812

Nesis KN (1970) Biocoenoses and biomass of benthos of the Newfoundland-Labrador region. Fish Res Bd Can Trans Ser 1375:1-75

Neyman AA (1960) Quantitative distribution of benthos on the shelf and upper continental slope in the eastern part of the Bering Sea. In: Moiseev (ed) Soviet fisheries investigations in the northeastern Pacific, Part I, p 143-150 (translated from Russian, Israel Program for Scientific Translations, US Department of Commerce, Clearinghouse for Federal Scientific and Technical Information, Springfield, VA)

Pownall $P$ (ed) (1994) Australia's northern prawn fishery: the first 25 years. NPF25, Cleveland, Australia

Rothlisberg PC, Pollard PC, Nichols PD, Moriarty DJW, Forbes AMG, Jackson CJ, Vaudrey D (1994) Phytoplankton community structure and productivity in relation to the hydrological regime of the Culf of Carpentaria. Australia, in summer. Aust $\mathrm{J}$ mar Freshwat Res 45:265-282

Sainsbury KJ (1987) Assessment and management of the demersal fishery on the continental shelf of northwestern Australia. In: Polovina J, Ralston S (eds) Tropical snappers and groupers: biology and fisheries management. Westview Press, Boulder, CO, p 465-503

Short JW, Potter DG (1987) Shells of Queensland and the Great Barrier Reef marine gastropods. Golden Press, Sydney

Somers IF (1994) Species composition and distribution of commercial penaeid prawn catches in the Gulf of Carpentaria, Australia, in relation to depth and sediment type. Aust J mar Freshwat Res 45:317-336

Somers IF, Long BG (1994) Notes on the hydrology of the Gulf of Carpentaria. Aust J mar Freshwat Res 45:283-292 
Stephenson W, Cook SD (1980) Elimination of species prior to cluster analysis. Aust J Ecol 5:263-273

Torgersen T, Hutchinson MF, Searle DE, Nix HA (1983) General bathymetry of the Gulf of Carpentaria and the quaternary physiography of Lake Carpentaria. Palaeogeogr Palaeoclımatol Palaeoecol 41:207-225

Tseythin VB (1987) Detritus flux to the ocean bed and benthic biomass. Oceanology 27:98-101

Ward TJ, Rainer SF (1988) Decapod crustaceans of the North

This article was presented by G. F. Humphrey (Senior Editorial Advisor), Sydney, Australia
West Shelf, a tropical continental shelf of northwestern Australia. Aust J mar Freshwat Res 39:751-765

Wenner EL, Read TH (1982) Seasonal composition and abundance of decapod crustacean assemblages from the South Atlantic Bight. Bull mar Sci 32:181-206

Wolanskı E, Ridd P (1990) Mixıng and trapping in Australian tropical coastal waters. In: Cheng RT (ed) Coastal and estuarine studies 38 . Residual currents and long-term transport. Springer-Verlag, New York, p 165-180

Manuscript first received: November 24, 1994

Revised version accepted: June 22, 1995 